\title{
Os sentidos no espetáculo ${ }^{1}$
}

\author{
Maria L aura V iveiros de Castro Cavalcanti \\ Professora do D epartamento de A ntropologia - IFCS/ UFRJ
}

\begin{abstract}
RESUMO : 0 artigo propõe a análise cultural da natureza espetacular de dois festivais populares contemporâneos: 0 desfile das escolas de samba no carnaval carioca e os Bois-Bumbás de Parintins, Amazonas. A investigação comparativa baseia-se na noção de corporalidade e focaliza os sentidos da visão e da audição na estrutura e dinâmica rituais de cada festa. A contextualização desses modos de percepção traz à cena processos cognitivos que, por sua vez, conduzem a valores culturais centrais, em especial noções diferenciadas de tempo e espaço. 0 jogo de significados acionado por essas concepções torna esses festivais momentos críticos de experiência e elaboração de formas diversas de estar na história e na modernidade.
\end{abstract}

PALAVRAS-CHAVE: corporalidade, cognição, percepção, espetáculo, ritual, cultura popular, tempo e espaço.

W hile the danœ thus brings into play the whole muscular system of the dancer it also requires the activity of the two chief senses, that of sight to guide the danœer in his movements amongst the others and that of hearing to enable him to keep time with the music. Thus the dancer is in a condition in which all the bodily and mental activities are harmoniously directed to one end. (Radcliffe-Brown, 1965: 248). ${ }^{2}$

A natureza espetacular de certas festas populares sempre me impressionou, tanto por sua beleza barroca, misturada, quase caótica, quanto por sua dimensão ritual e fortemente padronizada. Festas-potlatch, permeadas por intensa rivalidade, em que 0 trabalho, o talento e a energia de milhares de pessoas se consomem em alguns dias e horas de intensa e 
memorável experiência corporal. Festas-totais a imbrincarem muitos ângulos e aspectos da realidade cujo sentido integrado importa apreender (Mauss, 1978a) ${ }^{3}$.

Proponho a análise cultural da natureza espetacular de dois festivais populares contemporâneos: 0 desfile das escolas de samba no carnaval carioca (Cavalcanti, 1994 e 1999) e o festival dos Bois-Bumbás de Parintins, no Amazonas (Cavalcanti, 2000 e 2002). Tomo a noção de cultura na acepção antropológica forte, reiterando não se tratar aqui do "meramente simbólico", tantas vezes ouvido, sobreposto ao humano como um adorno final, sofisticada capa de seres já constituídos e consolidados (G eertz, 1973). A busca é pelo essencialmente simbólico, aquela teia de significações que abarca linguagem, pensamento e mundo, sujeito e objeto, num lance único, sempre refeito, arriscado e incompleto.

Nessa perspectiva, apresento a reflexão resultante de questões sugeridas pela análise comparativa dos dois festivais. 0 Bumbá de Parintins visto a partir do carnaval carioca e este carnaval revisto a partir do Bumbá indicaram um plano de sentido ainda não plenamente explorado em trabalhos anteriores. Este texto resulta, de certo modo, da experiência de estranhamento, identificação e relativização mútua trazida pelo diálogo constante que estabeleci com e entre as duas festas nos últimos anos.

Compreendo essas duas festas como modos da ação coletiva, de natureza processual, que dispõem padrões artísticos e narrativos únicos (Becker, 1982 e Simmel, 1971). Configuraram-se no contexto de amplos processos sociais (Turner, 1967; 1968 e Da Matta, 1979) e sua forma atual expressa a culminância de seus respectivos processos de expansão no país ${ }^{4}$. Suas respectivas narrativas rituais sintetizam essa singularidade contemporânea e fornecem a base da comparação proposta.

No diálogo estabelecido entre esses contextos festivos, pouco a pouco, a investigação dos usos e significados dos sentidos humanos da visão e da audição emergiu como eixo analítico proveitoso ${ }^{5}$. Seu exame conduz a valores culturais centrais, em especial, noções dife- 
Revista de Antropologia, São Paulo, USP, 2002, v. 45 no 1.

renciadas de tempo e espaço e maneiras também diversas de estar na história.

\section{0 corpo e o fato total}

Numa bibliografia vasta e complexa, sinalizo brevemente algumas referências a título de posicionamento analítico básico ${ }^{6}$. Mauss (1978b) é sempre um bom ponto de partida, a lembrar que não falamos sobre 0 corpo, mas sim a partir dele e com ele, esse objeto-sujeito de si mesmo, falamos daquilo que ele vê e apreende, e de como ele o faz. Mauss buscava, simultaneamente ao "fato total", o "homem total" (: 369), pois a compreensão do significado passa pela apreensão do ponto de vista nativo. 0 exemplo da caça do opossum na Austrália ilustra claramente a questão em jogo (: 370-71). N ela, uma fórmula ritual de caça e 0 ato mágico de levar na boca uma pedra de cristal tida como mágica associamse a uma difícil técnica que consiste em tirar o opossum de seu ninho no alto de uma árvore permanecendo suspenso através da cintura. Importa apreender, nos diz Mauss, a confiança do caçador, "o momentum psicológico que pode se articular a um ato que é antes de tudo um fato de resistência biológica, obtido graças a palavras e a um objeto mágico". Confiança resultante do caráter unitário que apresenta para 0 agente aquilo que nós distinguimos como um ato técnico, um ato físico e um ato mágico-religioso.

Essa simultaneidade e unidade de múltiplos pontos de vistas constitui o "homem total". Com a formulação sintética de que "a prova do social só pode ser mental", Lévi-Strauss (1978: XXVII, XVIII) desenvolveu com o brilhantismo usual um ponto latente nesse exemplo. 0 "mental" é por ele compreendido como o resultado de uma operação intelectual de transposição da apreensão interna/ subjetiva - a do nativo, ou a do observador que revive a experiência nativa - para uma apreensão externa/ objetiva que fornece os elementos de um conjunto apresentado de modo sistemático e coordenado. Ao definir a compreensão sociológica como 
o resultado sempre parcial de um processo teoricamente infinito de objetivação do sujeito, Lévi-Strauss traz implicitamente um terceiro interlocutor no diálogo travado com Mauss, Maurice Merleau-Pointy. Escrevendo em 1934, a fecundidade do caminho indicado por Marcel Mauss se originava no desejo muito simples de repararum erro fundamental: o de "só considerar a existência de uma "técnica" quando me deparava com a utilização de um instrumento. Era preciso retornar a noções antigas, aos dados platonianos sobre a técnica. Quando Platão falava de uma técnica da música e em particular da dança, e estender essa noção" (1978b: 371). A noção de técnica redefine-se então como todo ato coletivo e eficaz, tendo o corpo como primeiro e natural instrumento. Instrumento peculiar, nos diz ele, que é simultaneamente meio e objeto. As técnicas corporais, as maneiras pelas quais os homens em cada sociedade se servem de seu corpo, sentidas como naturais e entretanto imperceptivelmente construídas, erguem-se então como item fundamental de um idealizado inventário.

No prestígio de quem executa diante de outros um gesto logo assimilado e imitado, em arraigados hábitos corporais, como formas de andar e requebrar, de falar e escutar, combinam-se numa liga indissolúvel 0 psicológico e o biológico, o moral, o físico e o intelectual. Dividindo a humanidade em povos criados com berço e sem berço, povos acocorados e sentados, com mesa e sem mesa, chamando atenção para o papel fundamental da inibição em nossa vida social emental, seguro da necessária existência de "meios biológicos de entrar em comunicação com D eus", Mauss afirmava categoricamente que nada ocorre "de maneira natural" no adulto humano. Adaptamos permanentemente o corpo a seus usos através de técnicas, definidas como "montagens fisio-psico-sociológicas de séries de atos" (: 384) ${ }^{7}$. H abitus, cunha Mauss, designando com esse termo a natureza social e coletiva das técnicas corporais (: 368-69).

Merleau Pointy (1980) compreendeu e admirou Mauss, cujas idéias vinham ao encontro de seu empenho em trazer o pensamento da ciência para o solo do mundo sensível' ${ }^{8}$. Sem qualquer pretensão de imbrincar- 
me nos sempre densos emaranhados da filosofia, tomo para esta reflexão a idéia de que há um "pensamento", ou seja, uma forma de conhecer irredutível ao "pensamento falante", inerente ao exercício das faculdades humanas sensíveis (Merleau-Pointy: 1964)9. No ensaio "O olho e 0 espírito", a universalidade dessa proposta insinua-se na idéia de que 0 fundamental da pintura poderia sê-lo para toda cultura (: 15). A idéia é chave pelos desdobramentos antropológicos que comporta.

V ejamos mais de perto. Se é verdade que há na pintura uma primazia do visível, importa perceber que, ao pintar, o pintor empresta todo 0 corpo ao mundo para transformá-lo em pintura. É também com todo 0 corpo que apreendemos não exatamente esse ou aquele quadro, mas um certo aspecto do mundo tal como revelado por aquele quadro. As qualidades visualmente sensíveis dos objetos - luz, cor, profundidade - 0 são porque ecoam em todo o corpo, porque ele as acolhe. Não vemos, afinal, um mundo que está a nossa frente, mas que está por toda parte a nossa volta (: 58$)^{10}$. A pintura, portanto, não evoca simplesmente o tátil, ela revela aspectos do mundo, "dá existência visível àquilo que a visão leiga crê invisível" (: 29).

Se cada sentido humano comporta então operações ocultas, a pergunta do filósofo é como situá-las, e aos "filtros e os ídolos que elas preparam", no mundo do entendimento (:34-35). 0 que chamamos de visão abarcaria, mais precisamente, o caminho das coisas aos olhos e dos olhos ao pensamento. Visão "é a metamorfose das coisas em sua visão" (: 41), uma operação de decodificação de signos oferecidos pelos corpos e coisas. O ra, diz Merleau-Pointy, "essa filosofia por fazer, é ela que anima o pintor, não quando ele exprime opiniões sobre o mundo, mas no instante em que sua visão torna-se gesto, quando, dirá Cézanne, ele 'pensa pintura'" (: 60).

Embora as dimensões cognitivas da visão estejam patentes nessas formulações, fica claro que a visão não se reduz a uma forma de pensamento pois, embora não exista visão sem pensamento, não basta pensar para ver. Trata-se antes, nos diz 0 autor, de um "pensamento 
condicionado" que nasce "por ocasião daquilo que acontece ao corpo", sem escolher ser ou não ser, pensar isso ou aquilo. Do ponto de vista do sujeito, a visão traz intrinsecamente essa dependência da intrusão do que lhe provém de fora (: 51) e, como tal, seria mesmo um suporte fundamental do relacionamento com o mundo e os outros. Ver não é apropriar-se do mundo pelo olhar, mas uma maneira de aproximação, uma "abertura para" ${ }^{11}$. Por meio da visão, estabelece-se entre corpo e mundo, entre sujeito e realidade, um jogo de entrecruzamentos em que se superpõem "a precedência do que é sobre o que vemos e que faz ver, e daquilo que vemos e faz ver sobre o que é" (: 87). Nessa simultaneidade de operações a um só tempo inteligíveis e sensíveis consiste, mais exatamente, a visão.

Recruzamos fronteiras intelectuais retornando desse ponto a LéviStrauss, mas fronteiras amistosas entre territórios limítrofes, pois, na antropologia, Lévi-Strauss tomou como ninguém para si essas inspirações (1964; 1970; 1971) ${ }^{12}$. No humano de Lévi-Strauss, o corpo aparece certamente transmutado nas categorias sensíveis operadoras do inteligível. É um equívoco, entretanto, entendê-lo como o proponente de uma "razão desencarnada", um "intelectualista" ou "idealista" a despir nossa humanidade de sua carne e osso. Seu "inteligível" é simbolização, resultado indubitável de um magnífico empreendimento de alargamento e transformação de certa concepção de razão. A "razão" lévi-straussiana é, antes, totalmente encarnada em matéria, pois o pensamento humano é uma possibilidade dela. Em estado puro ou selvagem, no sentido em que se depara, em todas as épocas, como que sempre nu diante de um mundo a ser apreendido, a manipulação das qualidades sensíveis das coisas e seres, fornecida pela experiência corporal, é condição de seu exercício, sua forma primeira de ser. Interessa-nos também o fato de que, em Lévi-Strauss, o sensível que oferece ao pensamento suas categorias elementares é o sensível posto no solo etnográfico. A inteligibilidade das categorias empíricas - 0 cru e cozido, 0 alto e 0 baixo, 0 fresco e o podre, o molhado e o queimado entre outros pares e tríades 
Revista de Antropologia, São Paulo, USP, 2002, v. 45 no 1.

- deriva de contextos culturais particulares. Sem isso, seriam incapazes de realizar seu destino conceitual, capturadas pela máquina de fazer sentido do mundo, chamada mito por Lévi-Strauss.

Um caminho diverso daquele que será aqui seguido se delineia em torno da noção, muito corrente em certas áreas da antropologia contemporânea, de embodiment tal como proposta por Csordas (1990) ${ }^{13}$. Trata-se da elaboração de "uma perspectiva metodológica que encoraje a reanálise de dados existentes e sugira novas questões para a pesquisa empírica" (: 5). 0 noção assim erguida a conceito sintetizaria o almejado colapso analítico das clássicas dualidades mente e corpo, sujeito e objeto.

Aqui também as formulações de Merleau-Pointy embasam a discussão proposta sobre a percepção: 0 corpo humano deve ser tomado como a base existencial da cultura. No desenvolvimento do argumento, essas idéias ganham, entretanto, contornos muito diversos daqueles delineados na tradição que segue de Mauss para Lévi-Strauss, pois a elas somamse as formulações de Bourdieu sobre a "prática". D e Merleau Pointy, Csordas retém em especial a noção de "pré-objetivo". 0 pré-objetivo é 0 momento imediatamente anterior à constituição do objeto pelo sujeito. É o momento, diria Durkheim (1978), da transfiguração, 0 instante de transcendência em que o simbólico se instaura, instante logicamente simultâneo à constituição do objeto. Para Csordas, essa noção apreenderia analiticamente a experiência da percepção em sua riqueza e indeterminação, "o processo humano em aberto de considerar e habitar o mundo cultural, o qual nossa existência transcende embora permanecendo enraizada em situações de fato"(: 10).

De Bourdieu, Csordas trará em especial a noção de habitus, refraseada por sua vez pelo primeiro, com base na noção de Mauss. 0 habitus vem compensar, de certo modo, o que há de indeterminado no "pré-objetivo" e, assim fazendo, o argumento de Csordas começa a pender entre extremos. Pois vejamos só. Toda cultura, ao constituir a si e a seus nativos, é um se fazer dessa ou daquela maneira, excluindo sempre muitas outras maneiras possíveis. A indeterminação e riqueza do "pré- 
objetivo" é, então, sempre limitada pelo "objetivo", que imediatamente se segue, no mundo instituído onde existem sujeito/ objeto unificados em sua mútua constituição. Nesse raciocínio, o papel do conceito de habitus reformulado por Bourdieu é trazer à cena a inescapável determinação da cultura: "Um sistema de disposições permanentes que é 0 princípio inconsciente e coletivamente inculcado para a geração e estruturação de práticas e representações" (: 11).

No argumento de Csordas, a noção de habitus ocupa lugar análogo a certa noção de cultura, pois é ele, habitus, que "gera e unifica" a prática de modo sistemático, que conjuga "condições objetivas de vida e a totalidade das aspirações e práticas totalmente compatíveis com essas condições" (: 11). 0 argumento se desenvolve rumo ao jargão marxista, pois "a visão de mundo, organizada por estruturas cognitivas e avaliativas, corresponde a estruturas objetivas de um determinado estado do mundo social". Está certo que não são as condições objetivas que causam as práticas, ou vice-versa. Entre umas e outras temos o habitus, o mediador que faz com que práticas e idéias de dado sujeito (sujeito/ objetificado em suas práticas e idéias que o constituem como "corpo socialmente informado") pareçam sensatas e razoáveis. Ele é o princípio gerador das práticas e, em sua relação com o repertório total de práticas sociais, o princípio unificador. Numa volta do argumento, entretanto, as "estruturas objetivas do mundo social" terminam situadas para além da cultura/ habitus, erguidos, no final das contas, sobre elas, com a função cognitiva e moral de torná-las "sensatas" ${ }^{14}$. Na perspectiva da densa discussão antropológica tecida em torno da noção de cultura ${ }^{15}$, a de habitus opera a um só tempo de modo pouco preciso e muito determinista. 0 ponto indica uma dificuldade importante com a qual esbarra, a meu ver, 0 aspecto analiticamente interessante da noção de embodiment, 0 entendimento da cultura como um permanente ato da experiência corporal do sujeito ${ }^{16}$.

$\mathrm{Na}$ análise proposta, busco, num primeiro momento, a apreensão da percepção nativa do uso dos sentidos da audição e da visão via cate- 
Revista de Antropologia, São Paulo, USP, 2002, v. 45 no 1.

gorização. Partindo do contexto etnográfico de ambos os ritos, a análise caminha então rumo a um plano estrutural de significação, no qual esses sentidos nos conduzem a valores culturais centrais.

\section{0 estudo dos nitos}

Situada numa vertente de estudos central na antropologia, a noção de ritual pode ser conceitualmente banal se a tomamos como equivalente a comportamento simbólico tout court ${ }^{17}$, umavez que todo comportamento humano éinerentemente simbólico (G eertz, 1973). Retém uma dimensão mais interessante quando, seguindo Durkheim (1968), vemos nela a presença da "sociedade em ato". A ênfase recai, então, na ação/ comportamento, a base da "efervescência coletiva", trazendo consigo a instauração da autoconsciência mediatizada pelas representações. Em que pese a retórica dicotômica de Durkheim, o postulado teórico da necessária correlação, da consistência lógica e simbólica, entre esses dois planos analíticos - representações e práticas, ação e pensamento - que têm como sede concreta o indíviduo biológico, sugere a unidade do humano tão enfatizada por Mauss.

D o ponto de vista etnográfico, a noção é muito útil, como assinalou sensatamente Tambiah no curso de interessante reflexão (1985), ao indicar momentos distinguidos pelos nativos como especiais dentro da vida social rotineira. Com a qualificação aí implicita do tempo como composto de durações qualitativamente diferenciáveis entre si, temos embutida a discussão histónica eantropológica da construção de calendários e formas de marcação coletiva do tempo (Evans-Pritchard, 1969; Le Goff, 1984). D a Matta (1979) acrescentou à percepção do "extraordinário" (isto é, de alguma coisa sempre relativa ao "ordinário" de muitas maneiras possíveis ${ }^{18}$ a idéia do ritual como um dispositivo de deslocamento de perspectivas, propiciado por uma sociedade a si mesma. A partir do material bruto dos valores e representações sociais, projetando-os como imagens em espelhos deformadores (Seeger, 1980), os ritos construiriam, 
como formas da experiência viva, pontos de vista peculiares, e intercambiáveis, sobre 0 mundo social.

Com seu caráter repetitivo e tremendamente autoconsciente, haja vista 0 intenso preparo que sempre requerem, os ritos propiciam aos nativos aquilo que o trabalho de campo e o treino conceitual transformou em ofício antropológico: o estranhamento de si (Da Matta, 1978 e Velho, 1978); a exploração dos limites do culturalmente possível (LéviStrauss, 1996); a dramatização de tensões e contradições axiomáticas de um mundo social (Turner, 1967; 1968; e D ouglas, 1976). O rito, diz Da Matta, "dá asas ao plano social e inventa, talvez, nossa mais profunda realidade" (1979: 31). Nessa perspectiva, ritos são portas de entrada privilegiadas para a compreensão de uma sociedade, conduzem a seu centro vital do ponto de vista moral e cognitivo. Entre os muitos fatos que constituem nosso universo, os ritos são, como formula Leiris (2001: 11), espetáculos reveladores em que tangenciamos o mundo e a nós mesmos, trazendo à superfície elementos de nossa vida abissal.

Essas idéias embasam a comparação proposta. A elas acrescento 0 interesse em aprofundar a compreensão do idioma próprio dos ritos, buscando também seu enfoque como formas artísticas. Os teóricos do ritual insistem sempre, e corretamente, na forte relação dos ritos com um contexto, sempre peculiar, de relações sociais, e na maneira expressiva, dramática, performática ou comunicativa adotada para veiculá-las. Salta sempre aos olhos, entretanto, a maneira pouco econômica, mesmo em aparência totalmente despropositada, com que certos ritos o fazem. Para além do dispêndio conspícuo, tão bem percebido na reciprocidade agonística que embasa a noção do fato total ( Mauss, 1978a), a maneira de ser dos festivais com os quais venho trabalhando traz à cena uma dimensão propriamente artística e irredutível cuja análise tenho buscado aprofundar.

Da Matta ilumina um aspecto importante dos carnavais, em especial uma de suas formas, o desfile carnavalesco das escolas de samba, quando 0 interpreta como um ritual de inversão ${ }^{19}$. Se o compreendo 
Revista de Antropologia, São Paulo, USP, 2002, v. 45 no 1.

bem, não se trata simplesmente de inversão no sentido mais evidente de que nele os pobres aparecem no centro da cena, exibindo estonteantes nobreza (como no magnífico bailado do casal de mestre-sala e portabandeira) e talento (como na fantástica orquestra de percussão chamada bateria $)^{20}$. Seguindo o fio condutor de sua argumentação central, a idéia da inversão conduz a um plano de valores mais profundo, pois se trata de um rito individualizador e democratizante no seio de uma sociedade em muitos aspectos fortemente hierárquica. A idéia é valiosa pois, no desfile carnavalesco, contam o desempenho e o mérito num concurso que, existindo no Rio de Janeiro desde meados da década de 1930, se organiza em torno de regras de julgamento consensualmente redefinidas a cada ano. Trata-se efetivamente de um sistema aberto e competitivo que rebaixa e eleva, tendo incorporado novas escolas até o final do século XX. A comparação com o Boi-Bumbá desenvolve o argumento de que essa "modernidade" carnavalesca é também problematizada no simbolismo acionado pela forma narrativa de um desfile.

\section{Os dois ritos}

Carnaval e Boi-Bumbá são festas espetaculares. Nelas, o desenrolar do rito desvela extraordinária sofisticação artística. Nelas também, as fronteiras entre participantes e espectadores são fluidas e intercambiantes. Diferentes linguagens expressivas - música, dança e artes visuais imbricam-se, produzindo a polissemia que as torna atraentes a tantos e tão diversos grupos e camadas sociais. Enfoco essas formas expressivas tendo por base a discussão do uso e dos significados da visão e da audição tal como categorizadas e vividas em seus respectivos contextos rituais.

Retomo um caminho já indicado na interpretação proposta para o desfile carnavalesco (Cavalcanti, 1994) em que a oposição complementar entre as categorias nativas de "visual" e "samba" sintetizava a dinâmica do desfile como fato cultural. A oposição iluminava tanto a dimensão 
histórica do desfile (seu desenvolvimento rumo à atual configuração simbólica) como sua dimensão sincrônica (fosse ela o ciclo anual de confecção da festa ou o cerne do ritual propriamente dito, os 80 minutos de duração de cada desfile). Esse caminho interpretativo, revelado no modo etnográfico de apresentar os dados, era capaz de dar conta não só da tensão estrutural entre as diferentes linguagens artísticas do rito, como da tensão sociológica a permear as densas redes de reciprocidade que desembocam anualmente na festa. A compreensão do Bumbá de Parintins trouxe novo alcance ao argumento. Para desenvolvê-lo, apresento breve perfil histórico e etnográfico das duas festas.

\section{O camaval carioca}

D o ponto de vista cultural, o desfile festivo foi o centro articulador da formação das escolas de samba no Rio de Janeiro. 0 surgimento das escolas data da década de 1920 e, já no início dos anos 30, o desfile as agregava numa competição em cujo contexto definir-se-ia uma forma artística própria ${ }^{21}$. Ao longo do século XX, o desfile propiciou à cidade um canal de expressão e mediação de processos sociológicos importantes tais como a expansão da cidade rumo aos subúrbios e à periferia, a expansão das camadas médias e populares e sua interação, a importância crescente do jogo do bicho nas camadas populares.

Sumarizo aspectos desse desenvolvimento que interessam ao presente argumento. D o ponto de vista organizacional, isto é, pelo ângulo das relações estabelecidas entre o rito e a cidade, a competição carnavalesca gerou, com o correr dos anos, um sistema ritual apto a incorporar novas escolas (surgidas em diferentes bairros da cidade e seus arredores) e a eliminar escolas antigas (que, ou combinaram-se formando novas, ou simplesmente desapareceram). A tualmente, o desfile abarca cinco divisões, totalizando cerca de sessenta escolas de samba. A primeira, abrangendo quatorze escolas que desfilam na Passarela do Samba (o popular "sambódromo") nas noites de domingo e segunda-feira, é 
representada pela Liga Independente das Escolas de Samba ${ }^{22}$. 0 sambódromo tem cerca de 60 mil lugares e cada escola desse grupo desfila com 3 mil ou 5 mil componentes. De modo que, contabilizando apenas aqueles diretamente envolvidos no evento, temos cerca de $200 \mathrm{mil}$ pessoas reunidas na apresentação desse grupo ${ }^{23}$. Os demais grupos, representados pela Associação das Escolas de Samba do Rio de Janeiro, desfilam nas outras noites do carnaval, alguns no próprio sambódromo, outros na Avenida Rio Branco.

O campeonato organiza-se, então, em torno de uma estrutura inclusiva e aberta que promove anualmente as duas escolas vencedoras de cada grupo à divisão imediatamente superior e rebaixa as duas escolas perdedoras para a divisão imediatamente inferior. D e tal modo que, embora haja um núcleo aparentemente imbatível das chamadas "grandes escolas", essa "barreira" já foi "furada" em alguns momentos, caracterizando a possibilidade efetiva de trânsito por entre as divisões, num mecanismo capaz de agregar novos valores e segregar antigos que entraram em processos de queda e decadência ${ }^{24}$.

D o ponto de vista artístico, a forma do desfile completou-se na década de 1950. Data de então a definição do perfil atual e característico cuja base é a escolha anual de um "tema", logo desenvolvido como "enredo". A transformação do enredo nas linguagens plástica e visual das fantasias e alegorias, e rítmico-musical do samba-enredo, comanda a confecção do desfile. Conforme 0 ano caminha, esse processo reúne cada vez mais gente, alcançando a plenitude no rito, uma celebração de toda a cidade na qual o círculo social de cada escola alcança o seu máximo ${ }^{25}$.

Dito isso, focalizo o coração temporal e espacial do rito. As escolas desfilam no sambódromo, cuja pista de 700 metros é ladeada pelas arquibancadas. No desfile, cada escola deve percorrer essa pista em 80 minutos, narrando o enredo através de simultâneas linguagens expressivas, com o "visual" - as fantasias coloridas e os expressivos carros alegóricos - e com o "samba" - o canto do "puxador" acompanhado do canto 
coral de toda a escola e da bateria. 0 movimento dançado das alas, grupos com fantasias alusivas a temas específicos do enredo, conduz a evolução linear. Os carros alegóricos pontuam esse alinhamento, elaborando os principais tópicos do enredo. A dança ritmada e coletiva dos corpos conduz a escola em movimento linear, integrando o "visual" ao "samba", unindo as dimensões festiva e espetaculares do desfile.

Numa apresentação bem-sucedida, a distinção entre espectadores e brincantes torna-se, senão totalmente abolida, muito diminuída. Do ponto de vista do brincante, integrante da narrativa, cantar e dançar fantasiado numa ala é também ser visto e admirado, e isso é parte da brincadeira. Do ponto de vista do espectador, aquele para quem 0 enredo é "contado", ver e admirar são atividades que acompanham 0 cantar e o dançar. Em muitos momentos, o espectador torna-se um brincante que não apenas saúda a passagem da escola mas que se une efetivamente a ela, como um participante especial. É muito comum um desfilante voltar para as arquibancadas após a passagem de sua escola para usufruir como espectador/ brincante o desfile das outras escolas.

Visão e audição estão aqui intimamente conectados; a dança e 0 canto coletivos e ritmados expressam sua intensa associação na criação de um contexto em que, quem dança e canta, também vê e é visto. Q uando um sambista explica a um leigo o significado de dois items de julgamento, a evolução e a harmonia, ele dirá que a evolução pode ser julgada por uma pessoa surda e a harmonia por uma pessoa cega ${ }^{26}$. Referida ao entrosamento entre ritmo da percussão e canto coral das alas, a harmonia privilegia o instante. É um quesito de base auditiva, pois é pelo ouvido que o brincante une seu canto ao dos demais, obedecendo ao ritmo percussivo coletivo. Essa adequação é então "julgada" no quesito. Esse ouvir aciona entretanto processos sinestésicos decisivos, pois é pela união da visão a essa audição que o brincante/ cantor organiza, por sua vez, sua dança coletiva e progressiva, o que nos traz à evolução. Referida ao movimento de uma escola na pista, a evolução é um quesito de base eminentemente visual, a acionar especialmente 0 olhar de quem julga 
Revista de Antropologia, São Paulo, USP, 2002, v. 45 no 1.

ou assiste. Ao implicar, em alguma medida, a apreensão de uma totalidade, a evolução supõe uma posição de relativa exterioridade no desenrolar do desfile.

O desfile propõe assim ao olhar uma posição especial, responsável pela apreensão de uma informação crucial trazida por sua forma narrativa. A formação completa de uma escola de samba compreende comissão de frente e abre-alas, conjunto das alas pontuado pelos carros alegóricos (oito atualmente) e entremeado pela ala das baianas, porta-bandeira e mestre-sala, "puxador" e "empurradores" (os intérpretes do samba na avenida, o pessoal do "gogó"), bateria e velha guarda. Em termos ideais, a única possibilidade de apreensão dessa totalidade é visual e quanto mais alto se estiver nas arquibancadas, melhor. Na prática, essa formação não se completa nunca e uma escola jamais está inteira na pista ${ }^{27}$. Passados 35/ 40 minutos do início de um desfile, a comissão de frente e 0 abre-alas já começam a sair pela porteira final (que se abre apenas com a sua chegada); e apenas aos $50 / 55$ minutos os últimos componentes da escola terão entrado na pista. Só então o portão que marca o início do desfile se fecha ${ }^{28}$. 0 preenchimento do espaço da pista é regulado por uma espécie de sistema de comportas que se abrem e se fecham em seqüência. Uma vez aberto o portão que marca o início da contagem do tempo, o portão final abrir-se-á 35/ 40 minutos depois e, uma vez fechada a porteira inicial, a porteira final fechar-se-á 35/ 40 minutos depois. Quando os dois portões estão fechados ao mesmo tempo, 0 espaço está totalmente vazio. A pista então só fica inteiramente cheia no intervalo de tempo em que a porteira da extremidade final já se abriu e a inicial ainda não se fechou; ou seja, durante cerca de 20 minutos, menos de um quarto da duração de um desfile ${ }^{29}$.

Uma impressão fundamental deriva dessa percepção visual: uma escola "passa" como um fluxo compacto que não deve ser detido por nenhum acidente de percurso (um vazio causado pelo atraso de um grupo de alas, por uma falha mecânica num carro alegórico, pelo tombo de uma porta-bandeira... ). Essa percepção visual de um fluxo, ao implicar 
uma certa relação entre tempo e espaço, traz informações cognitivas importantes. Retenho o ponto para a comparação com o Bumbá.

Por ora ressalto que, se a visão traz, mais do que a informação, 0 desejo nunca satisfeito de completude ou totalidade, e se essa informação requer distância e exterioridade, pois a melhor posição aqui é, indubitavelmente, a do espectador situado no alto da arquibancada ${ }^{30}$, essa "exterioridade" só pode ser apreendida de dentro (Merleau-Pointy, 1980). A evolução de uma escola não indica um movimento ao qual se assiste, mas um movimento do qual o espectador é parte integral. 0 olhar que acompanha vive a passagem de uma escola na pista, requerendo a companhia simultânea do samba, cuja letra e melodia integrais são repetidas pelo menos 50 vezes ao longo do percurso ${ }^{31}$. Um bom sambaenredo, dizem os entendidos, é aquele que, quanto mais cantado, mais vontade se tem de cantá-lo. Essa qualidade imprevisível, só revelada na passarela, chama-se de "rendimento" do samba. 0 samba que "rende" favorece a dança e a adequação de seu ritmo ao canto, propiciando uma evolução "leve" e "solta" da escola.

Assim é que "passar bem", o ideal almejado de toda escola, embora corresponda tecnicamente ao quesito visual da "evolução", resulta da sinestesia entre visão e audição ao longo do desfile. Q ualquer inadequação entre percussão e canto coral, ou dificuldade experimentada no canto, afetará não apenas a "harmonia", mas também a evolução. Uma escola que "passa bem" é, afinal, aquela que motiva os espectadores a tornarem-se também brincantes, a cantarem e a dançarem durante toda a performanœ. A boa passagem é uma passagem cheia. E então ela terá sido.

\section{O Boi-Bumbá de Parintins/ Amazonas}

O Festival dos Bois-Bumbás ocorre anualmente na cidade de Parintins/ Amazonas, situada no arquipélago das Tupinambaranas, bem próximo à fronteira com o estado do Pará, na região conhecida como Médio 
Revista de Antropologia, São Paulo, USP, 2002, v. 45 no 1.

Amazonas, em função de sua posição bem no meio do curso do grande rio. 0 Bumbá é uma variante, espetacular e massiva, do ciclo mítico da brincadeira do boi, registrada no país desde as primeiras décadas do século XIX (Cavalcanti, 2000).

Os grupos de boi surgiram na cidade a partir das primeiras décadas do século XX. A memória oral reteve a data dos dois primeiros: Boi Garantido - o boi vermelho e branco com um coração na testa, criado em 1913 - e Boi Caprichoso - o boi azul e preto com uma estrela na testa, surgido logo em seguida ${ }^{32}$. O utros bois existiram, porém, apenas Garantido e Caprichoso permaneceram, ocupando hoje o centro da cena festiva. Algumas razões embasam esse peculiar dualismo que ganhou vida em Parintins.

As bases territoriais das redes de relações dos grupos Garantido e Caprichoso, respectivamente situadas a oeste e a leste da cidade, tornaram-se aos poucos uma oposição importante na morfologia e organização social urbanas. Parintins, cidade totalmente plana, pensase em relação ao leito do rio, distinguindo entre a parte de "baixo" e a parte de "cima" que congregam redes de famílias e parentelas distintas. A sociabilidade dos dois grupos agregou essas diferentes redes de relações. D esde sua fundação até a década de 1960, os dois grupos apresentaram-se na forma tradicional, percorrendo as ruas da cidade nos dias do santos juninos e enfrentando-se em brigas severas que deixaram marca na memória local. Não se destacavam, então, dos demais folguedos existentes na cidade, como as quadrilhas juninas e as pastorinhas natalinas. A criação do "Festival Folclórico de Parintins", em 1965, ao formalizar o confronto entre os dois grupos, trouxe um processo de mútua emulação; o festival tomou-se um sucesso conforme os Bois tornavam-se a sua principal atração, expressando sua tradicional rivalidade através de uma padronização artística que vem, desde então, sofisticando-se. A década de 1990, em especial, com marcada ênfase indianista, definiu a atual forma de ser que serve de referência à análise. $\mathrm{O}$ confronto, agora festivo, entre os dois Bois associou-se assim 
fortemente à representação da unidade da cidade, cuja fama chegou à capital estadual, espalhando-se em toda a região norte.

De tal modo que, ainda nos dias de hoje, à oeste, ou "para cima", situa-se o Boi Garantido, seu "Curral" (a quadra de ensaios) e seus "QGs" (Q uartéis-G enerais, as oficinas de confecção das alegorias e das fantasias dos grupos). No lado leste, ou para "baixo", fica o Boi Caprichoso, seu "Curral" e "QGs". De tal modo que, caminhar para 'cima' (oeste) ou para 'baixo' (leste) nas ruas de Parintins é adentrar a rede de relações de um dos Bois Bumbás, embora certamente de forma não tão marcada como outrora.

A construção do "bumbódromo", em 1988, consagrou essa dualidade e seu lugar central na representação unitária da cidade ${ }^{33}$. 0 estádio é uma estrutura de concreto armado, com cerca de 45 mil lugares nas arquibancadas erguidas ao redor de uma arena. Situado na área urbana central, o bumbódromo alinhou-se com o cemitério local, a catedral de Nossa Senhora do Carmo, a praça municipal e o porto, traçando uma linha imaginária que divide Parintins ao meio. A arena e as arquibancadas elaboram internamente essa divisão do espaço exterior. A metade oeste, pertencente à "galera" vermelha, abriga os torcedores do "G arantido". A metade leste, pertencente à "galera" azul, os torcedores do Boi "Caprichoso" 34 .

Atualmente, nas noites de 28, 29 e 30 de junho, Caprichoso e G arantido, cada qual com cerca de 3.500 brincantes, revezam-se na arena do Bumbódromo em espetáculos de cerca de três horas de duração. A limitação da competição a dois contendores é contrabalançada pela elaboração interna da performanœ. A cada noite, mantendo um mesmo modelo de apresentação, os grupos renovam suas fantasias, carros alegóricos e lendas.

Os personagens básicos relacionam-se ao núcleo mítico da brincadeira do boi. Um boi precioso, dado por um rico fazendeiro a sua filha querida, é morto por um vaqueiro de confiança para satisfazer um desejo de sua mulher grávida. 0 fazendeiro descobre 0 crime e suspenderá a punição 
Revista de Antropologia, São Paulo, USP, 2002, v. 45 no 1.

ao vaqueiro se este ressuscitar o boi. Um médico e um padre tentam e fracassam. Finalmente, um pajé realiza o feito seguido do perdão e da reconciliação festiva ${ }^{35}$. Em Parintins, esse núcleo semântico ampliouse e deslocou-se, trazendo para si 0 ambiente amazônico e a cultura cabocla com suas lendas e criaturas sobrenaturais, as diferentes culturas indígenas regionais, muitas histórias de destruição de grupos antigos e a defesa ecológica da mata. De tal modo que as apresentações anuais acrescentaram um slogan ao tema da morte e da ressurreição do boi, que permaneceu como pano de fundo. 0 slogan é um tema-título, derivado desse universo simbólico regional mais amplo. 0 resultado é uma performanœ fragmentada, organizada em torno de pequenas seqüências dramáticas dançadas, em que se sucedem eventos que conduzem a um clímax final.

Um componente notável das apresentações é a partipação das "galeras", instaladas em suas respectivas metades das arquibancadas. $0 \mathrm{~s}$ assentos destinados a elas são gratuitos e correspondem a $80 \%$ do espaço disponível. Lá, a galera - um quesito de julgamento - saúda o seu boi, cantando, dançando e produzindo muitos efeitos especiais. Na hora do espetáculo do oponente, a galera permanece sentada, em silêncio profundo (ela perderia pontos importantes se prejudicasse 0 rival). Assim é que, do ponto de vista do torcedor, há duas formas alternadas de participação: ou você canta, dança e produz efeitos visuais, ou você escuta e aprecia quieta, cuidadosa e muito criticamente enquanto 0 oponente preenche, de modo gradual, a totalidade da arena. Por isso, numa formulação benévola, as pessoas dizem que, em Parintins, "amase um boi e admira-se o outro".

A fora a galera (que já está lá aguardando), o apresentador (o primeiro a entrar em cena), o levantador de toadas (o segundo a entrar em cena), seguido pelas orquestras de percussão (batucada no Garantido ou marujada no Caprichoso), não há ordem fixa para a entrada dos demais personagens. Toadas diversas acompanham os diferentes momentos cênicos e a performanœ conclui-se sempre com uma seqüência dramática 
denominada "ritual". Para além disso, as demais cenas, incluindo a do boi e seu séquito, são livremente encadeadas. 0 s personagens individuais - a Cunhã Poranga (moça bonita em tupi), a sinhazinha da fazenda, 0 boi, a rainha do folclore, e o pajé - geralmente entram em cena trazidos por alegorias e acompanhados por toadas específicas. Sua aparição é sempre saudada com foguetório e efeitos especiais.

Alguns elementos, como os maravilhosos tuxáuas, cujas fantasias são em si mesmas pequenas alegorias, adentram a arena, desfilam e se vão. A maior parte dos brincantes, entretanto, permanece na arena, especialmente as "tribos" masculinas e femininas, grupos de jovens com fantasias de inspiração indígena que, com coreogafias definidas, gradualmente preenchem a arena, ocupando integralmente o espaço disponível com o seu Boi. Quando a arena está cheia, começa o "ritual", o apogeu da apresentação que corresponde à principal encenação do pajé, sempre um extraordinário bailarino. D epois disso, todo o grupo, movimentandose em círculos, retira-se da arena.

No Bumbá, num contexto corporal também fortemente sinestésico e graças à forma totalmente interna e definida de participacão da galera na apresentação, as fronteiras entre espectadores e brincantes são mais nítidas e fortemente diluídas do que no carnaval. Contudo, a apreensão da dinâmica do espetáculo repousa, aqui também, em uma noção decisiva derivada de percepção visual. Aqui também o melhor lugar é o alto da arquibancada, supondo igualmente uma posição de relativa exterioridade, nesse caso estruturalmente contida na idéia da apreciação crítica do oponente. $O \mathrm{~s}$ artistas do Boi freqüentemente comparam-se ao carnaval carioca. Um tópico favorito de comparação são as alegorias - um empréstimo cultural intencional (alegorias foram introduzidas no Bumbá na década de 1970, por um artista parintinense amante e conhecedor do carnaval carioca). Entretanto, eles logo acrescentarão: no carnaval, as alegorias "passam diante dos olhos", no Bumbá elas "acontecem".

Essa percepção é chave para a compreensão da dinâmica narrativa do Bumbá. Um grupo de boi preenche gradualmente a arena - com suas 
tribos, principais personagens, entrada dos carros alegóricos para a definição das sucessivas cenas acompanhadas pelas toadas e pela dança coletiva, denominada localmente de "bailado". Esse preenchimento gradual e sucessivo traz um sentido de acúmulo cuja tensão é sempre provisoriamente liberada em um clímax, um "acontecimento" - uma seqüência especial de ação, acompanhada de toadas especiais, fogos de artifício e efeitos visuais. Tudo rumo ao clímax final que corresponde ao preenchimento apoteótico da arena e a seu esvaziamento subseqüente. A boa apresentação, pontuada por apogeus, digamos, de intensidade média, desenvolve-se em direção a uma apoteose dramática alcançada no momento da ocupação plena da arena, transformada em território exclusivo de um dos dois grupos. Tudo então se esvai, para recomeçar nas noites seguintes.

\section{Linhas e círculos: tempo, espaço e maneiras de estar na história}

"It seems that the Christian calendar has been followed for centuries by the Iberian C atholics in a way that has meant an intimate association of the ritual meaning of religious popular festivals with a whole conception of life (... )".

(Freyre, 1975: 143)

Num pequeno e luminoso artigo, Gilberto Freyre (1975) chamou a atenção para a particularidade da noção de tempo dos ibéricos nos séculos XVI eXVII. Já seria sabido e aceito que os ibéricos, descobridores e navegadores pioneiros, detinham um sentido de espaço mais avançado e científico, diverso da maior parte dos demais europeus de então. Sua noção de tempo, entretanto, seria também peculiar e defasada com relação à de espaço, pois operaria dentro de parâmetros muito mais tradicionais, aproximando-os do sentido de tempo arcaico, próximo do 
tempo cíclico do homem "primitivo" (Eliade, 1991). 0 argumento de Freyre desenvolve-se na direção do conhecido elogio da colonização ibérica que teria trazido vantagens culturais e psicossociais do ponto de vista do contato humano no contexto do empreendimento colonial ${ }^{37}$. Retenho aqui o ponto, fortemente antropológico, das conseqüências sociológicas da existência em ato de uma certa noção de tempo. Ao contrário do tempo veloz e cronometrado, de ritmo constante progressivo, consagrado na idéia do "tempo é dinheiro", o tempo agido pelos ibéricos seria o tempo a serviço do homem. Fluindo lentamente e na ausência de sistema predeterminado, essa noção de tempo permitiu a criatividade e o surgimento de novas modalidades culturais no contato com os povos não europeus, ao contrário do que Freyre chama da "exclusividade paneuropéia sistemática dos demais europeus". Nesse sentido, o cristianismo católico dos ibéricos - que diante dos demais povos teriam enfatizado, acima de sua condição européia e nacional, sua condição sociologicamente cristã - os teria aproximado dos povos não europeus por meio de um tempo que não era simples adequação ao trabalho contínuo, com apenas o domingo dedicado ao descanso, mas um tempo em que muita alternação entre trabalho e lazer, dança e labor, era propiciada pela própria igreja. Produziu-se assim uma temporalidade que, mais do que histórica, remeteria a uma série de ritos míticos relacionados à renovação da vida, uma vida qualitativa, mais do que uma série de atividades lógica e quantitativamente valoráveis.

O ra, o cristianismo, em sua versão católica, foi efetivamente um elemento decisivo na configuração da chamada cultura popular brasileira ${ }^{38}$. A comparação entre os significados cosmológicos do carnaval carioca e do Bumbá de Parintins fala em favor dessa interpretação, pois ambos são festas profanas imersas no calendário cristão católico, do qual extraem plano importante de seu sentido mais pleno. Situam-se, entretanto, em níveis e posições distintas nessa temporalidade.

O carnaval pertence ao tempo de datas móveis, comandado pela morte e ressurreição de Cristo, àquela ordem passional que, desdobrada 
Revista de Antropologia, São Paulo, USP, 2002, v. 45 no 1.

ao longo dos séculos, conformou o rumo dominante do ano cristão, ganhando, como já propôs Caro Baroja (1979), sentido amplo quando contraposto à quaresma ${ }^{39}$. Em suas diversas nuances e modalidades, 0 carnaval traz consigo a oposição entre corpo e alma, central à civilização cristã. É sempre afirmação da carne, do aqui, do agora, do que já vai se acabar e, por isso mesmo, afirma a pura duração, esgotando-se em excessos múltiplos por oposição à mortificação, à penitência, à culpa $\mathrm{e}$ ao desejo de redenção na eternidade. 0 corpo do carnaval é o corpo sexuado, não necessariamente o corpo bonito ou cuidado que se exibe num carro alegórico, ou na concorrida posição atual das "madrinhas de bateria", mas muitas vezes simplesmente corpo, da dona de casa barriguda, do comerciário magrelo, da menina caolha, do garoto míope e de pernas tortas, que se divertem brincando numa ala. Corpo que toma para si as tênues fronteiras entre liberdade, liberalidade e libertinagem desembocando na sugestão insinuante de pecado, na certeza da morte sempre reafirmada na quarta-feira de cinzas. Um corpo que gostaria de ser só corpo sem transcendência alguma.

O Bumbá, por sua vez, integra 0 calendário santoral aberto às peculiaridades de cada terra diferenciada dentro da cristandade, com datas fixas e cheias de coloridos locais. No norte do Brasil, o Bumbá pertence ao ciclo dos santosjuninos: São Pedro, São João, Santo Antônio e São Marçal ${ }^{40}$. A natureza profana do Boi é, de certo modo, menos marcada ${ }^{41}$. Em Parintins, os dois grupos mantêm ainda promessas aos santos juninos, e ambos levam à efervescência da arena a imagem da Santa Padroeira da cidade, Nossa Senhora do Carmo, cantando nos momentos adequados verdadeiras preces em forma de toada. 0 corpo no Boi é devoto e grave, mesmo em suas mais puras expansões de alegria, corpo diferenciado de homens e mulheres que marcam na festa sua distinção nas tribos exclusivas e, quando nus, aspiram, numa espécie de paródia pungente, à inocência civilizatória daqueles povos "que foram outrora os donos da terra". A concepção de corpo sugerida por cada uma dessas festas é radicalmente distinta. 
Ambas festas existem, entretanto, na nossa história contemporânea. Um aspecto decisivo de sua significação repousa no encontro, momentâneo e crítico, entre diferentes temporalidades por elas propiciado. Um ponto central de sua manufatura coletiva é, justamente, a elaboração de mecanismos simbólicos que desenvolvem e correlacionam noções diferenciadas de tempo. D uas delas delineam-se nitidamente nesse exame: a concepção ocidental moderna do tempo como uma linha pontuada por acontecimentos irreversíveis (Meyerson, 1956) e a percepção tradicional do tempo como um ciclo, que termina e recomeça, como que retornando sempre ao mesmo ponto de partida (Eliade, 1991). Um tempo mais próximo da concepção mítica que, como diria Lévi Strauss (1970), tenta transformar o evento em estrutura, a diacronia em sincronia, o recente no antigo, repetindo diante de dados novos uma mesma maneira de lhes extrair significado.

Em cada caso, o uso e a definição ritual do espaço concretizam e problematizam o jogo entre diferentes temporalidades. 0 sambódromo e o bumbódromo escolheram respectivamente a linha e o círculo como formas básicas de seu espaço ritual. A través da visualidade do espaço, da lógica de seu uso pela dinâmica de suas respectivas narrativas, esses rituais nos trazem diferentes noções do tempo e de sua passagem. Nesse sentido, a preeminência da visão na apreensão dessa informação, essa visão integrada e sinestésica acionada nos contextos festivos que procurei apreender, é a razão cultural primeira do caráter espetacular de ambas as festas.

No desfile carnavalesco, há prevalência do tempo sobre o espaço. A pista é linha, neutralizada, vazia e homogênea. Em seu percurso ritual, o tempo será fluxo contínuo e irreversível, passagem linear que não deve ser interrompida - como "um rio que passou em minha vida, e meu coração se deixou levar", cantado por Paulinho da Viola. O tempo flui ao longo do espaço como em direção a um futuro indefinido. Porém, nesse futuro, ainda que incerto, o carnaval voltará! Pois esse tempo mais "moderno" se aninha dentro do ciclo ritual cristão e repetitivo de um 
Revista de Antropologia, São Paulo, USP, 2002, v. 45 no 1.

ano. No cerne ritual, entretanto, como condição para a competição, 0 tempo é quantitativamente homogeneizado pela cronometragem. 0 fragmento de tempo de 80 minutos é neutro nesse sentido, abstratamente idêntico e vazio diante de seu preenchimento que será o desfile. Essa "obediência ao relógio", medida exata que incomoda a tantos puristas, é assim peça-chave de ritualização, pois será totalmente subvertida e transformada em duração cheia, pelo uso e vivência qualificados desse fragmento de tempo.

0 desenvolvimento do desfile expressa como que uma revolta contra a linearidade espacial e narrativa por ele assumida. Pois vejamos bem: em sua vivência concreta, o tempo de sua duração é, de certo modo, multiplicado, ou melhor, estilhaçado em mil cacos, pela maneira nada linear de apresentar um "enredo". 0 termo "enredo", extraído deformas eruditas de criação artística e utilizado na expressão corrente de "enredos carnavalescos", é profundamente enganoso. 0 enredo funciona apenas parcialmente como princípio organizador da narrativa ritual. 0 termo indica, no ponto de partida do processo de criação coletiva, um ideal de unidade que assegura de fato uma espécie de moeda simbólica comum sempre pronta a ser trocada, desfeita ou renovada em muitos outros sentidos expressos simultaneamente em diferentes linguagens artísticas. Não há, entretanto, num desfile unidade ou coerência de sentido que resista por mais que um breve instante. Um desfile corresponde ao esquartejamento visual dos enredos, subdivididos em múltiplos tópicos, que se abrem, por sua vez, em muitos outros numa cadeia infindável, ou melhor, que só se fecha por necessidade externa: o tempo de sua apresentação se esgota. Os enredos são assim remendados, triturados, expandidos nos tópicos representados nas alegorias e desdobrados nas fantasias. Tudo se complica ainda mais pois, enquanto visualmente há desdobramento e multiplicação, musicalmente há reforço e repetição.

Um samba-enredo é repetido inúmeras vezes ao longo do percurso ritual, ancorando o enredo em apenas alguns motivos básicos. Os 
carnavalescos, em especial, gostam de compará-lo a uma trilha sonora (a idéia seria a de um suporte musical do que é apresentado visualmente, como num filme em que a imagem comanda a ação e seu desenrolar). A comparação é forçada e estálonge de expressar a tensão complementar, cheia de inversões e subversões, estabelecida entre "samba" e "visual" na narrativa do desfile. Repetindo-se sempre, quase à exaustão, alimentando o movimento linear e progressivo da escola em desfile, o samba é uma "trilha" de natureza muito peculiar.

O samba-enredo não sustenta uma ação comandada pela imagem, ele é, antes, a razão de ser do próprio movimento, ele não segue nada, antes conduz e alimenta o movimento da escola como um campo de presença. 0 samba é cantado ao vivo, no "gogó", e seu intérprete é um "puxador" pois, de fato, ele "puxa" o samba com a sua primeira passagem solo no momento final da concentração da escola, quando 0 desfile está prestes a irromper. A cronometragem do desfile começa quando, acompanhado pela percurssão da bateria e pelo canto coral das alas, o samba põe a escola em movimento, rompendo o portão inicial. Um samba gostaria de repetir a si mesmo eternamente, de ser ouvido para sempre. Essa repetição (que encantou o compositor minimalista Philipp G lass no desfile de 1991), pela tentativa de negação do fluxo linear que lhe é implícita, assemelha-se a uma forma de querer a eternidade.

A escola passa e cada pedaço é visualmente diferente, mas traz consigo sempre o samba que, igual a si mesmo, retorna sempre. 0 sentido da visão traz novidades e acontecimentos em fragmentos de significado. A audição, por sua vez, relaciona essas imagens em fluxo irreversível a um conjunto semântico fixo e reversível. Um carro alegórico corresponde àquele pedaço de samba e, depois que tiver passado, sem ter nunca sido completamente visto, não retornará jamais. Porém, enquanto durar o desfile, o canto repetido a ele aludirá facilitando a captura desses muitos sentidos que fluem em uma forma fragmentária e moderna de integração da experiência. 
Revista de Antropologia, São Paulo, USP, 2002, v. 45 no 1.

Submetendo-se ao tempo linear, o desfile concreto de cada escola é, por essa razão, uma rebeldia contra ele, cada desfile realmente 0 carnavaliza na mais pura acepção bakhtiniana do termo ${ }^{42}$, bagunça-0, abre-o desordenadamente, libertando-o de qualquer univocidade. Por isso, aquele tempo que irremediavelmente passa torna-se também um tempo que, enquanto dura, não quer se acabar. 0 desfile é, inicialmente, um fragmento de espaço a ser preenchido por um fluxo de tempo; graças ao jogo sinestésico entre visão e audição, os termos dessa equação tornam-se intercambiáveis. Tempo que embora não queira passar, passa e muda, mas retorna sempre, ainda que diferente, "no ano que vem". Pedaço de espaço idêntico eneutro a ser percomido por vários contendores, que cedem lugar um ao outro. Estamos no centro da cidade, mas a passarela propriamente dita não tem centro, é linha.

No Bumbá, o espaço prevalece sobre o tempo. Não se trata aqui de passagem, mas sim de território, a ser qualificado e ocupado. A arena é um círculo no coração da cidade a ser preenchido num fragmento de tempo, cuja cronometragem define e enfatiza apenas seus limites externos: uma duração excepcional na qual a totalidade do espaço pertencerá exclusivamente a apenas um dos grupos. A alternância na forma de participação das galeras é significativa. Trata-se de um uso da visão e da audição nos moldes de Radcliffe-Brown (1965), seja como sentidos integrados ao uso total do sistema muscular no canto e na dança, seja como associados à inibição do movimento muscular que produz 0 silêncio e a quietude. Visão e audição permanecem constantes nas duas posições alternadas e a diferença se estabelece a partir da ativação e inibição da musculatura dançante e "cantante". A ativação do movimento relaciona-se à adesão e à afirmação de uma identidade que culmina na ocupação integral da arena. A inibição do movimento, por sua vez, relaciona-se à civilidade que controla a rivalidade - é hora do outro apresentar-se. No entanto, essa apresentação não ocorre, como no desfile carnavalesco, ao longo de um espaço "neutro" pelo qual se passa. Vimos como uma escola não "ocupa" a pista do desfile - ocupar seria 
parar e parar, ainda que por breve instante, seria perder. Na passagem de uma escola, a ênfase está posta no tempo, em sua linearidade concretizada e rebatida no espaço da pista. No Bumbá, diversamente, não se trata simplesmente de assistir à apresentação do adversário, de respeitar e tolerar seu direito à existência, e mesmo a possibilidade de sua superioridade no campeonato. Trata-se, mais do que isso, de vê-lo ocupando integralmente um espaço que, ao menos naquela duração, não se deseja ver dividido. Como esse espaço, tornado território por sua ocupação, não pode ser definitivamente nem de um nem de outro, pois a realização desse desejo traria consigo o risco de destruição da própria identidade, e tampouco interessa a sua divisão, a solução é alternar sua ocupação. A totalidade da arena é, a cada turno, inteiramente minha ou tua. Tua necessária presença, condição da minha existência, é sempre vitória ou derrota. $O$ etos aqui é guerreiro. Inibir é experimentar tolerar o que parece intolerável; a inibição, condição da "civilidade", tem 0 sabor selvagem de uma sempre possível derrota, o silêncio alude à humilhação de ver, e vivenciar como possível, a ocupação pelo outro de um território reivindicado como exclusivamente seu. 0 espaço é 0 centro de referência desse universo, ele tem aqui primazia, o uso do tempo está a seu serviço. Importa a mais apoteótica ocupação da arena.

Se o tempo é aqui um ciclo de plenitude e exaustão, um tempo que sempre termina e recomeça, é importante lembrar que o Bumbá escolheu pequenas narrativas cênicas para a composição de suas seqüências dramáticas. O ra, vale notar que essas sequiências trazem no seu desenrolar o sentido da irreversibilidade com a irrupção da "supresa" e com a noção de "acontecimento" tão característica do tempo histórico e cronológico (Meyerson, 1956).

O diálogo proposto pelo exame do uso dos sentidos da visão e da audição nos dois festivais relaciona diferentes noções de tempo e de espaço, cuja elaboração emerge como fonte primordial de significação. No carnaval, o tempo é transformado em puro fluxo e é representado desse modo através da neutralização e da linearidade do espaço ritual; 
Revista de Antropologia, São Paulo, USP, 2002, v. 45 no 1.

no Bumbá, o espaço ritual é transformado em território a ser ocupado, operação possibilitada pela reversibilidade do tempo em ciclo de morte e renascimento. Esse jogo de significados, acionado por essas diferentes noções de tempo e espaço, torna esses festivais momentos críticos de elaboração de formas diferenciadas de estar na história. O Bumbá, com sua natureza claramente mítica, toma decidido partido da temporalidade cíclica e tradicional. Porém, mais do que isso, problematiza-a também ao manifestar intenso e "moderno" interesse pela irrupção de "acontecimentos", surpresas irreversíveis, dentro do ciclo reversível de morte e ressurreição. O desfile, por sua vez, intrinsecamente moderno em sua apropriação de uma concepção linear do tempo que flui, revoltase contra a inexorável irreversibilidade dessa passagem e estilhaça-a em mútliplas linguagens superpostas, adensando o instante, e acabandose afinal em cinzas, que se acenderão novamente em fogo e brasa no ano vindouro.

A maneira de utilizar o referencial semântico que organiza as duas festas tem também o que dizer sobre sua qualidade histórica. No carnaval, o "enredo", condutor do desenrolar do rito, é um dispositivo flexível que, ao garantir a continuidade de uma forma artística, é também capaz de renovar seu conteúdo semântico, datando-0 anualmente ${ }^{43}$. No Bumbá de Parintins, a alusão ao tema mítico da morte e ressurreição do bicho precioso veio conviver com um tema anual oriundo do imaginário regional. Vale notar que a categoria nativa para esse tema é slogan, que tem justamente a intenção explícita de diferenciar-se do "tema" ou do "enredo" do carnaval carioca. Essas matrizes semânticas superpostas integram-se apenas parcialmente no desenrolar da performance. Se é verdade que esse desencaixe acentua o caráter fragmentário típico de todas as formas da brincadeira do Boi, ele acentua também o compromisso da festa com o tempo cíclico de seu mito de referência.

Essas estruturas simbólicas guardam também importante vínculo com a organização social mesma de suas competições, estabelecendo relações diversas com as cidades que as promovem. 0 Bumbá opera 
dentro de um sistema fechado e totalizador, consagrando um dualismo característico da cidade que o criou. A possibilidade de sua ampliação repousa na reprodução desse dualismo alhures, desenvolvimento que parece por sinal estar em curso na região norte do país com a proliferação de inúmeros festivais promovidos em diversas localidades entre dois contendores. Fenômeno até agora eminentemente regional, o Bumbá revela a contemporaneidade e os esforços de reformulação de um universo social de base tradicional ${ }^{44}$. 0 desfile, por sua vez, desenvolveu um esquema competitivo essencialmente aberto. Esse mecanismo permitiulhe identificar-se, ao longo do século XX, com a redefinição e 0 crescimento de uma metrópole que problematiza através dele a sua própria "modernidade".

A natureza e o sucesso espetaculares de ambos os festivais repousam assim sobre consistentes bases culturais, aqui propostas à investigação antropológica da cultura popular contemporâna.

\section{Notas}

1 Este texto veio se desenvolvendo nos últimos dois anos, ao longo de encontros acadêmicos e culturais. Na origem, conversas estimulantes com José Reginaldo Gonçalves me fizeram acreditar que, embrulhado então em idéias confusas, havia mesmo um caminho a seguir. Ricardo Benzaquen Araújo, com habitual generosidade, trouxe precioso aporte bibliográfico. Agradeço aos participantes da mesa-redonda "Sensuous epistemologies", coordenada por Katherine Y oung, na $99^{\circ}$ reunião da AAA ( 2000, São Francisco, EUA); aos participantes do Laboratório de Análise Simbólica do PPG SA/ IFCS (maio de 2001, RJ), em especial J. R. G onçalves, Marco Antônio G onçalves, Elsje Lagrou, Márnio Teixeira, Wagner Silva, Marcos Veneu e Ana Maria Galano; aos participantes do seminário "O Corpo na vida contemporânea" (Programa Rio Arte de Apoio à D ança/ Paço Imperial, agosto de 2001), em especial a Márcia Milhazes, Cássia Navas e José Miguel Wisnik; aos participantes do Seminário de Antropologia, do D epartamento de Antropologia da USP, em novembro de 2001, quando pude contar com os valiosos comentários de José Guilherme Magnani, Wagner Silva, Márcio Silva e Lilian Schwartz. 
2 Tradução livre: "A dança não só aciona todo o sistema muscular do dançarino como também requer a atividade dos dois sentidos capitais, a visão que guia 0 dançarino em seus movimentos entre os outros e a audição que lhe permite seguir o ritmo da música. Assim, o dançarino encontra-se em uma condição em que todas as atividades corporais e mentais estão harmoniosamente dirigidas para uma finalidade".

3 Não há racionalidade econômica, objetivo turístico, interesse eleitoral que, isoladamente, dêem conta da natureza dessas festas que, ao contrário, impõem suas dinâmicas muito próprias ao vasto conjunto de pressões que as configura. Ver a respeito Lanna (1995). V ale lembrar Lévi-Strauss (1978) assinalando que 0 "fato total" não consiste na simples integração de aspectos descontínuos da realidade, mas antes em sua definição como realidade e em sua interpretação como sistema.

4 Remeto o leitor interessado nos aspectos históricos e etnográficos dos dois festivais a meus trabalhos anteriores.

5 A discussão da corporalidade associada à construção da noção de pessoa foi elaborada por D a Matta, Seeger eV iveiros de Castro (1979). Numa contribuição teórica original da etnologia indígena brasileira à teoria antropológica, as noções de corporalidade e pessoa foram então propostas como princípios ordenadores da própria experiência e estruturas sociais.

6 A noção de "corpo", conforme muitas noções-chaves na antropologia- como "símbolo", "linguagem", "cultura" - abarca grande diversidade de percepções e nuances teóricas, confundindo-se com a própria configuração da disciplina. Além da vertente "francesa" aqui ressaltada, vale mencionar os trabalhos seminais de Radcliffe-Brown (1965), Turner (1967; 1968) e D ouglas (1966; 1973; 1975). Os dois últimos destacam-se pela elaboração da noção de corpo como poderosa fonte de metáforas sobre a sociedade.

7 Lévi-Strauss dirá: “Chaque technique, chaque conduite, traditionellement apprise et transmise, se fonde sur certaines synergies nerveuses et musculaires que constituent de véritables systèmes, solidaires de tout un contexte sociologique" (1978: XIII), assinalando (:XIV) o valor do empreendimento maussiano que, diante das concepções racistas que insistem em ver o homem como um produto de seu corpo, vê, ao contrário, o corpo como um produto das técnicas e representações humanas. 
8 Ver a respeito Chauí (1980).

9 Optei por utilizar a versão francesa original, traduzindo livremente os trechos citados. Para a tradução brasileira, ver Merleau-Pointy, (1980).

10 O mundo é assim um "campo de presença", como assinala Chauí (: XI), em que meu corpo associa-se a outros de muitas maneiras.

11 Ver é "o meio que me é dado de ausentar-me de mim, de assistir de dentro à fissão do Ser, apenas ao termo da qual volto a fechar-me sobre mim" (: 81).

12 A afinidade existente entre as formulações de ambos e mútua admiração foi explicitamente assumida pelos dois. Ver, em especial, notas 1 e 3 da tradução do artigo “D e Mauss a Claude Lévi-Strauss" (Merleau-Pointy, 1980: 193 e 194).

13 Em especial, vertentes das antropologias "médica" e "psicológica" nos Estados Unidos e, no Brasil, os estudos sobre cura e religião. A tradução de embodiment em portugês é um problema digno de nota. A palavra mais próxima e óbvia seria incorporação. Na forte tradição brasileira dos estudos antropológicos da religião, o termo está contudo desde sempre firmemente vinculado à discussão do transe, mediunidade e possessão. Teríamos então, como opção, o neologismo "encorporação".

14 Senão vejamos: "Aquela parte das práticas que permanece obscura aos olhos de seus próprios produtores éo aspecto pelo qual eles são objetivamente ajustados a outras práticas. 0 princípio de produção da estrutura dessas práticas é o próprio produto dessas" (Bourdieu, 1977 apud Csordas, 1990: 12).

15 Vale mencionar, entre tantos, Bateson (1958), Sahlins (1976), G eertz (1973), Clifford (1998). Para um bom apanhado do debate contemporâneo em torno da noção de cultura, ver Gonçalves (1996).

16 Csordas tem o objetivo mais específico de analisar movimentos cristãos religiosos contemporâneos dos EUA, em especial autilização de imagísticas multisensoriais em seus serviços de cura. A demonização, por exemplo, évista como processos corporificados de objetivação do self. Embora demônios tenham existência representacional anterior, realça-se o fato de que, paraos participantes, a experiência do exorcismo (i.e, da presença e expulsão da entidade que está dentro do corpo) 
é vivida como espontânea e sem conteúdo pré-ordenado, o queimplica apreender o caráter permanentemente construído da cultura. Porém, o permanentemente construído retorna para a idéia de "pré-determinado", pois essa vivência sentida como indeterminada é, entretanto, padronizada pelo habitus em sua expressão gestual. Se é verdade que a validade de todo o argumento, como nos alerta 0 autor, é o emprego da noção de corpo como figura metodológica não opostaà mente, pergunto-me se o vice-versa seria cabivel no raciocínio. A ânsia de contraporseao "representacional" parece acarretar uma simplificação da noção de "mente".

17 Mesmo levando em conta que, na oposição entre comportamento técnico e comportamento simbólico, estamos lidando com uma questão de ênfase analítica, essa é uma das dificuldades de conhecida definição de Leach (1972).

18 Essa variação na maneira de relacionar-se com o cotidiano desdobra-se, em D a Matta (1979), na análise da trilogia ritual composta dos "carnavais, paradas e procissões", respectivamente rituais de inversão, reforço e neutralização das relações sociais. Na perspectiva da discussão que sucederá, ressalto que essas três formas rituais utilizam a linha como modelo de desenvolvimento espacial.

19 Para uma interpretação mais ampla desse livro de D a Matta, ver Cavalcanti (2000).

20 Poderíamos alargar ainda esse primeiro plano da idéia de inversão incluindo o fato de a festa tipicamente sem dono ter terminado, no Rio de Janeiro, nas mãos da obscura máfia do jogo do bicho (Cavalcanti, 1999). Só a dimensão libertária e subversiva contida no rito carnavalesco confere plausibilidade cultural a esse escândalo anual com o qual convivemos de modo, senão tranquilo, ao menos resignado.

21 Tupy (1985) traz datas esclarecedoras do início dessa fase de estruturação das escolas de samba: 1931- data do primeiro concurso segundo a tradição oral; 1932 - data do primeiro desfile noticiado pelos jornais locais; 1935 - data do primeiro concurso promovido pela prefeitura com a inclusão das escolas na subvenção oficial ao carnaval. Antes disso, nas primeiras décadas do século, a originalidade do samba, como canção e coreografia populares urbanas, já emergira com força no cenário nacional.

22 Para discussão detalhada da Passarela do Samba, ver Cavalcanti (1994: 28-31); para o jogo do bicho no carnaval ver, em especial, Cavalcanti (: 32-41), e 0 artigo "O mecenato do jogo do bicho no carnaval carioca", em Cavalcanti (1999). 
23 Sem contar mídia, segurança, serviços, público alcançado pela transmissão, etc.

240 quadro das datas de fundação das escolas participantes do desfile do grupo especial no camaval de 2000 é revelador: Porto da Pedra (Niterói), 1978; G rande Rio (D uque de Caxias), 1988; Vila Isabel (Vila Isabel), 1946; Caprichosos de Pilares (Pilares), 1949; Tradição (Madureira), 1984; Mocidade Independente de Padre Miguel (Bangu), 1955; Portela (Madureira), 1923; Unidos da Tijuca (Santo Cristo), 1931; Mangueira ( Mangueira), 1928; Salgueiro (Tijuca), 1953; Imperatriz Leopoldinense (Santo Cristo), 1959; Ilhado Governador ( Ilha do Governador), 1953; Beija Flor de Nilópolis ( Nilópolis), 1955; Unidos de Viradouro (Niterói), 1946. A década de 1950 é o mais intenso período de formação de novas escolas. As décadas subseqüentes, 1960 e 1970, emergem como períodos de marcante transformação.

25 D a Matta (1979) realçou o papel das alas nessa forma de organização social "em cometa" que, preservando um centro geralmente personalista de decisões, é altamente agregadora e expansiva. Observo que há muitos ensaios ao longo desse processo, mas nada semelhante a um ensaio geral. O s componentes do espetáculo reúnem-seapenas no momento dafesta Emboraaltamentepadronizado, o desfile preserva assim um grau de espontaneidade que suscita surpresas e expectativa.

26 Esses dois quesitos diferem dos demais em sua natureza simbólica cuja análise conduz à dimensão estrutural do rito. Os outros quesitos são: enredo, sambaenredo, bateria, comissão de frente, mestre-sala e porta-bandeira, conjunto, alegorias e adereços e, finalmente, fantasias.

27 Essas conclusões baseiam-se na observação dos desfiles das grandes escolas que, contudo, apenas radicalizam um efeito presente em todos os demais.

28 E, antes dele, o portão da concentração. Para a descrição mais detalhada do momento de início do desfile, ver Cavalcanti (1994: 123-25).

29 Observo que, tendo assistido e participado dos desfiles nas mais diversas posições e condições desde 1984, só pude precisar essas observações em 2002, quando fui assisti-lo com esse objetivo explícito. 0 desfile constrói e, de certo modo, ensina essa possibilidade do olhar que, diga-se de passagem, é inapreensível e 
instransmissível pelos meios televisivos atuais. Para usarmos a expressão de Merleau-Pointy, o desfile como fato cultural pleno é um campo de presença.

30 Ver a respeito Moraes (s.d.).

31 Se um desfile dura 80 minutos e cada passagem de samba-enredo, cerca de um minuto e meio, temos aproximadamente 53 repetições. Se incluirmos o período da concentração nesse cálculo, chegamos facilmente a sessenta repetições.

32 Há quem diga no mesmo ano, há quem diga no ano seguinte. Para pesquisa detalhada sobre o Bumbá de Parintins, ver também a tese de doutoramento de Braga (2001).

33 O bumbódromo chama-se oficialmente "Ginásio Amazonino Mendes"em homenagem ao então governador do estado que voltaria ser eleito nos períodos de 1994-1998 e 1998-2002 .

34 No Bumbódromo, há apenas quatro áreas neutras, localizadas ao norte e ao sul do estádio. Ao sul, situada entre os dois grandes portais da arena, está a "Tribuna de Honra", destinada ao govemo municipal e a membros ilustres da comunidade. As outras três áreas localizam-se ao norte: um conjunto de cabines para o juri; acima dele, um conjunto de assentos para os jornalistas; e, no topo do estádio, um extenso conjunto de cabines, especialmente construído pela Coca-Cola para seus convidados (socialites, artistas, empresários, jornalistas e autoridades brasileiras). D esde 1995, a Coca-Cola patrocina o festival, somando-se ao govemo estadual, Ministério da Cultura eaos próprios Bois, hoje gerentes de seus negócios.

35 Estou trabalhando em uma análise de variantes do mito do Boi recolhidas em diferentes regiões brasileiras.

36 Tradução livre: "O calendário cristão parece ter sido seguido por séculos pelos católicos ibéricos de uma maneira que significou uma íntima associação do significado ritual dos festivais religiosos populares com toda uma concepção de vida".

37 Para a problematização desse elogio, ver A raújo (1994). 
38 Certamente, nas últimas décadas, a expansão das seitas protestantes junto às camadas populares vem tornando a cultura popular brasileira muito mais multicultural do que em seu período de formação (fins do século XVIII e século XIX em especial).

39 Para uma discussão específica da relação do desfile com o tempo, ver Cavalcanti (1999).

40 VerSalles (1970).

41 Paraas "festas de santo", ver Lanna (1995), Brandão (1985), Zaluar (1983), G alvão (1962), Wagley (1957).

42 A carnavalização como capacidade de renovação e relativização do mundo (Bakhtin, 1987).

43 Para a relativização dessa datação, que na memória coletiva transforma-se num registro governado pela lógica ritual anual de todo o processo, ver Cavalcanti (1999).

44 Penso especialmente nas formulações de Da Matta, no final de “Panema” (1973).

\section{Bibliografia}

ARAÚJO, R. B.

$1994 \quad G$ uerra epaz: Casa grande\& senzala ea obra de G ilberto $F$ reyre nos anos 30, Rio de Janeiro, 34.

BATESON, G.

$1958 \quad$ N aven, California, Stanford University Press.

BAKHTIN, M.

A cultura popular na Idade M édia eno Renascimento, São Paulo, Hucitec. 
BRAGA, S. G.

2001 "Os Bumbás de Parintins", São Paulo, tese, FFLCH-USP.

BRANDÃO, C. R.

1985 A festa do Santo Preto, Rio de Janeiro/ Goiás, Funarte/ Ed. Universidade Federal deG oiás.

BECKER, $\mathrm{H}$.

1982 A rt W orlds, California, University of California Press.

CARO BAROJA, J.

1979 L eCarnaval, Paris, G allimard.

CAVALCANTI, M. L.

1994 Carnaval carioca: dos bastidores ao desfile, Rio Janeiro, FUNARTE/ UFRJ.

19990 rito e o tempo: ensaios sobre o carnaval, Rio de Janeiro, Civilização Brasileira.

2000 "O Boi-Bumbá de Parintins: breve história e etnografia da festa”, R evista H istória, Ciência e Saúde: V isões da A mazônia, Rio de Janeiro, vol. VI: 10191046, nov., Suplemento especial.

2002 "O indianismo revisitado pelo Boi-Bumbá: notas de pesquisa”, Revista de E studos A mazônioos. Somanlu, Programa de Pós-graduação em Natureza e Cultura na Amazônia, Amazonas, ano II, n. 2: 127-35, Edição especial.

CHAUÍ, M.

1980

"Merleau-Ponty (1908-1961): vida e obra", in M erleau-Pointy, São Paulo, Abril Cultural, Coleção Os Pensadores, pp. VI-XIII.

CLIFFORD, J.

1998

"A experiência etnográfica”, in G O NÇALVES, J. R. (org.), A ntropologia e literatura no século X X , , Rio de Janeiro, UFRJ.

CSORDAS, T.

1990

"Embodiment as a Paradigm for Anthropology", E thos, Journal of the Society for Psychological A nthropology, vol. 18(1): 5-47, mar.

DA MATTA, R.

1973

"Panema: um exercício de análise estrutural", in E nsaios de A ntropologia estrutural, Petrópolis, Vozes. 
1978 "O ofício do etnólogo, ou como ter anthropological blues", in NUNES, E. (org.), A aventura sociológica, Rio de Janeiro, Zahar.

1979 Carnavais, malandros e heróis. Para uma sociologia do dilema brasileiro, Rio de Janeiro, Zahar.

DA MATTA, R., SEEGER, A. \& VIVEIROS DE CASTRO, E.

1979 "A construção da pessoa nas sociedades indígenas brasileiras", B oletim do Museu N acional, Nova Série, Antropologia, n. 32: 2-19.

DOUGLAS, M.

$1973 \quad$ Natural Symbols. Ex xlorations in Cosmology, Londres, Pelikan Books.

1975 Impliat M eanings. E ssays in A nthropology, Routledge \& Kegan Paul.

1976 Pureza eperigo, São Paulo, Perspectiva.

DURKHEIM,É.

1968 L as formas elementales dela vida religiosa. E 1 sistema totemion en A ustralia, Buenos Aires, Schapire, Introducción, Livro II, Cap. 7, Conclusion.

ELIADE, M.

1991 The myth of the eternal return. Or Cosmos and H istory, Princeton University Press.

EVANS-PRICHARD, E. E.

1969 The N uer. A description of the modes of livelihood and political institutions of a N ilotic people, New Y ork/ Oxford, O xford University Press.

FREYRE, G.

1975

"On the Iberian concept of time", in 0 brasileiro entre os outros hispanos: afinidades, ontrastes e possíveis futuros nas suas inter-relacōes, Brasília, MEC/ INL, pp. 132-44.

GALVÃO, E.

1962

Santos evisagens.U m estudo da vida religiosa deItá, A mazonas, São Paulo, Cia. Ed. Nacional.

GEERTZ, C.

1973

The interpretation of cultures, New Y ork, Basic Books. 
GONÇALVES, J.R.

1996 "A obsessão pela cultura”, C ultura, substantivo plural, Rio de Janeiro/ São Paulo, Centro Cultural Banco do Brasil/ 34, pp. 159-83.

LANNA, M.

1995

A dívida divina. Troca e patronagem no $\mathrm{N}$ ordeste brasileiro, Campinas, Ed. Unicamp.

LEACH, E.

1972

"Ritual", in International E ncydopedia of Social Science, vol. 13-14, New Y ork, The Macmillan Company \& The Free Press.

LE GOFF, J.

1984

"Calendário", in E ncidopédia E inaudi, Lisboa, Imprensa Nacional/ Casa da Moeda, Memória-História, vol. I, pp. 260-92.

LEIRIS, M.

2001

E spelho da tauromaquia, São Paulo, Cosac\&Naify.

LÉVI-STRAUSS, C.

1964 "Le cru et le cuit", in M ythologiques I, Plon, Paris.

19700 pensamento selvagem, São Paulo, Cia. Editora Nacional/ Edusp.

1971 "L'homme nu", in M ythologiques IV , Plon, Paris.

1978 "Introduction à l'oeuvre de Marcel Mauss", in Sociologie et A nthropologie, Paris, Presses Universitaires de France, pp. IX - LII.

1996 Tristes trópicos, São Paulo, Companhia Das Letras.

MAUSS, M.

1978a "Essai surle don: formeet raison de l'échange dans les sociétés archaiques", in Sociologie et anthropologie, Paris, Presses Universitaires de France, pp. 143279, (Extrait de l'A nnée Sociologique, seconde série, 1923-1924).

1978b "Les techniques du corps", in Sociologie et anthropologie, Paris, Presses Universitaires de France, pp. 365-86, (Journal de Psychologie, vol. XXXII(34), 15 de mars - 15 avril 1936, Communication présentée à la Société de Psychologie le 17 mai 1934.). 
MERLEAU-POINTY, $\mathrm{M}$.

1964 L'oeil et l'esprit, Gallimard, p. 93, Folio essais. [Tradução: MERLEAUPONTY, Maurice. 0 olho e 0 espírito, São Paulo, Abril Cultural, 1980, pp. 85-111, Coleção O s Pensadores.

1980 "De Mauss a Claude Lévi-Strauss", in M auriœ M erleau-Pointy, São Paulo, Abril Cultural, pp. 193-206, Coleção O s Pensadores.

MEYERSON, I.

1956

"Le temps, la mémoire, l'histoire", Journal de Psychologie normale et patologique, 53 ème. année, n. 3: 333-54, jui-sept.

MORAES, F.

S.d.

"Carnaval: a primazia do visual", in Chorei em Bruges: crônicas de amor à arte, Rio de Janeiro, Avenir.

TUPY, D .

1985

Carnavais de guerra. 0 nacionalismo no samba, Rio de Janeiro, ASB Arte.

RADCLIFFE-BROWN, A. R.

1965 TheA ndamam Islanders, University of Chicago, The Free Press.

\section{SAHLINS, M.}

1976

C ulture and Pracical Reason, Chicago, Chicago University Press.

\section{SALLES, V.}

1970

"O Boi-Bumbá no ciclo junino", Brasil A gucareiro, Rio de Janeiro, vol. 38: 27-33, jun.

SEEGER, A.

1980

O s índios e nós. E studos sobre sociedades tribais brasileiras, Rio de Janeiro, Campus.

SIMMEL, G.

1971

"Social forms and inner needs" e "The transcendent character of life", in LEVINE, D onald (ed.) $0 \mathrm{n}$ individuality and social forms, Selected writings, Chicago/ London, The University of Chicago Press. 
TAMBIAH, S.

1985

"A performative approach to ritual", CultureThought and social action. A n anthropological perspective, Cambridge/ Massachussets, Havard University Press, pp. 351-74.

TURNER, V.

1967

The F orest of Symbols, Ithaca, Cornell University Press.

1968

The D rums of A fliction. A study of religious Processes among the $\mathrm{N}$ dembu of Zambia, Comell University Press.

VELHO, G.

1978

"O bservando o familiar", in NUNES, E. (org.), A aventura sociológica, Rio deJaneiro, Zahar.

WAGLEY, C.

1957

U ma comunidade amazônica, São Paulo, Cia. Editora Nacional, Coleção Brasiliana, vol. 290.

ZALUAR, A.

1983 Os homens de D eus, Rio de Janeiro, Zahar. 


\begin{abstract}
The paper presents a cultural analysis of the spectacular nature of two contemporary Brazilian Festivals: the samba-school parade in Rio de Janeiro and the $\mathrm{Ox}$-D ance in Parintins/ Amazonas. The concept of corporality provides the starting point for the investigation of the uses and meanings of sight and hearing in the ritual structure and dynamics of each festival. Considered in their respective festive contexts, these modes of perception illuminate cognitive processes which, in turn, reveal central cultural values, in particular, conceptions of time and space. The play of meaning between these two conceptions renders both festivals critical moments for the experience and elaboration of different ways of relating to history and modernity.

KEY-WO RD S: corporality, perception, cognition, ritual, popular culture, time and space.
\end{abstract}

Recebido em abril de 2002. 